\title{
日本におけるフェアトレードの出版物発行数と新聞記事数の変遷
}

小倉亜紗美*

\section{Changes in the numbers of publication and newspaper articles about fair trade in Japan}

Asami OGURA*

キーワード：フェアトレード, 出版物, 新聞記事, ソーシャルビジネス

Key words : Fair trade, Publications, Newspaper articles, Socially responsible business

\section{1. はじめに}

フェアトレード (fair trade) とは, 開発途上国 の原料や製品を適正な価格で継続的に購入するこ とにより，立場の弱い開発途上国の生産者や労働 者の生活改善と自立を目指す「貿易のしくみ」のこ とである ${ }^{1)}$ 。その目標の一つとして, 持続可能な生 産を保障するため環境に配慮した生産活動の実施 が定められている。1946 年にアメリカの非政府組 織 $\left(\mathrm{NGO}^{2)}\right)$ によって始められ, その後, 欧米を中 心にその活動が広がったと言われており（FLO な ど, 2008), 1989 年にはフェアトレード団体を繋ぐ 国際的なネットワーク「国際フェアトレード連盟 $\left.(\mathrm{IFAT})^{3)}\right\rfloor$ がヨーロッパで設立され, 世界 61 カ 国の 270 のフェアトレード団体が加盟した ${ }^{4}$ 。1 1994 年にはワシントン D.C. で国際的なフェアトレー ドネットワーク「フェアトレード連盟 $\left.(\mathrm{FTF})^{5)}\right\rfloor$ が, 1998 年にヨーロッパで非公式なネットワーク $\left\lceil\mathrm{FINE}^{6)} 」\right.$ が設立され，2001 年に FINE が統一的 なフェアトレードの定義に合意した。その後「国 際フェアトレードラベル機構 $(\mathrm{FLO})^{7)} 」 に よ り$, 2002 年に初めて世界統一の国際フェアトレード 認証ラベルが導入され, 2004 年にはムンバイで開 かれた世界社会フォーラムでIFAT がフェアト レード団体マークを発表した。同年, FINEがブ
リュッセルに合同フェアトレード・アドボカシー・ オフィスを設立し, 2005 年には既存のフェアト レード基準, 定義, 手続きの調和・改善プロジェ クト「品質管理制度 (Quality Management System)」が開始された（FLOなど，2008）。そ して, 2008 年にIFAT は「世界フェアトレード機 関（WFTO）に名前を変更した（WFTO, 2009）。 2012 年末時点で 71 ケ国の 386 団体が WFTO に加 盟し, 情報を共有しながらフェアトレードの普及 を目指している（WFTO，2013）。

日本では, 1972 年に設立した特定非営利活動法 人「シャプラニール =市民による海外協力の会」 が 1974 年からバングラデシュの手工芸品の生産 と販売を始めたのがフェアトレードの始まりと言 われている ${ }^{8)}$ 。その後フェアトレードを行う非営 利活動法人（NPO）や企業が少しずつ増え, 1993 年にはフェアトレードラベル推進組織「トランス フェアジャパン」(2004 年に「フェアトレード . ラベル・ジャパン（FLJ)」に名称を変更）が設立 された 9)。トランスフェアジャパンは, 日本国内 において(1)国際フェアトレード認証ラベルのライ センス事業と製品認証事業, (2)国際フェアトレー ド認証ラベルの普及推進活動, (3)フェアトレード の教育啓発活動, (4) FLO 事業への参加（フェア トレード基準や方針の策定，生産者支援，資金調

*広島大学平和科学研究センター, 730-0053 広島市中区東千田町 1-1-89, asaminno@hiroshima-u.ac.jp 
達等）の 4 つの役割を担っている。2004 年には フェアトレードを考える大学生を中心としたネッ トワーク $\mathrm{FTSN}^{10)}$ が設立され, 設立以来毎年「フェ アトレード学生サミット」を開催している。さら に2011年 4 月に一般社団法人フェアトレードタウ ン・ジャパン 11) が設立され，2011 年 6 月に熊本 市がアジア初, 2015 年 9 月には名古屋市が日本で 2 番目のフェアトレードタウンとして認定され た。2014年 9 月 17 日現在国際フェアトレード認 証を取得した認証・登録組織は 100 件に上る ${ }^{12) 。 ~}$

このような社会動向の中で, フェアトレードに 関する書籍は翻訳本を含め多く出版され, イン ターネット上はもちろん, テレビや新聞, 雑誌な どのメディアで取り上げられている。これらが フェアトレードの社会的関心を高めるために果た す役割は大きいと考えられる。実際に 2007 年と 2013 年に日本で行われた調査で, テレビ, 新聞, 雑誌が消費者の主な情報源となっており（日本新 聞協会広告委員会, 2014) ${ }^{13)}$, フェアトレードを既 に認知している人の情報源に関する調査では，テ レビ, 新聞, 杂誰誌の順に多かったことが報告され ている（チョコレボ実行委員会マーケットリサー チチーム, 2008) ${ }^{14)}$ 。

今後, 日本においてフェアトレードの普及をさ らに推進するためには, 日本におけるフェアト レードの普及状況・社会的関心の度合いを把握し, それらの向上のために適切な方策を練る必要があ る。このうち, 日本におけるフェアトレードの普 及状況については, 長坂が 2008 年に発行した著書 の中で, 2005 年までの日本のフェアトレード団 体, 販売店舗についての現状を初めて網羅的に報 告している（長坂, 2008a）。2009 年には財団法人 国際貿易投資研究所が日本のフェアトレード市場 について初めて本格的な調查を実施した結果が報 告されている（長坂, 2009)。また, 渡未（2010） は, フェアトレードの歴史と欧米と日本における いくつかの企業のフェアトレードの取り組みにつ いて調べ報告している。ただ, 出版物や新聞など のメディアによるフェアトレードの扱い方，ある いは揭載数についての研究はほとんどされてこな かった。これらを把握することは, 販売者側によ る消費者へのアピール内容やフェアトレード市場 の拡大を間接的に明らかにする一助になるばかり
でなく，ここ数年の倫理的な消費や社会貢献ビジ ネスの高まりをとらえる上でも前提となる情報で あると考える。そこで本稿では, 日本におけるフェ アトレードに対する社会的な関心の変遷を明らか にし，フェアトレードを含む環境配慮商品の市場 の拡大に貢献するため, 日本におけるフェアト レードに関する出版物と新聞記事の発行数・掲載 数の歴史的推移を調べ, 国内のフェアトレード市 場の動向との関係性について考察した。

\section{2. 日本におけるフェアトレードに関する出版 物と新聞報道の変遷}

\section{1 フェアトレードに関する出版物発行数の推移}

国立国会図書館 ${ }^{15)}$ が提供している検索サービス 「国立国会図書館サーチ (NDL Search)」16)で, 2014 年 7 月 4 日に「フェアトレード」をキーワードに 検索したところ，439 件の資料が確認された（そ のうち 9 件の資料は重複して表示されたので, 重 複を除いて解析した)。資料はそれぞれ,「図書, 記事・論文 ${ }^{17)}$, 新聞 ${ }^{18)}$, 博士論文, 雑誌, 映像資 料, 政府刊行物, 立法情報, オンライン情報, 参 考情報, 分類なし」（以後，この分類を示す際には ［］で表す）に分類されていたので，それぞれの 分類ごとの発行数の推移を調べた（表 1)。同様に 2014 年 7 月 18 日に「Fair Trade」をキーワード に検索したところ，2,465 件の資料が確認された が, 2014 年 7 月 4 日に「フェアトレード」で検索 した資料も含まれており，さらに，多くの資料は 「Trade Fair」（貿易博覧会）や単純に「Trade」 （貿易）についての資料が多く，また第二次世界大 戦後の GHQ の資料が多く含まれていたので, 解 析の対象としなかった。1973 年に 1 件, 1992 年に 2 件の [雑誌] が発行されているが, これらの雑 誌には本稿で扱っているフェアトレードについて の記述はなかった。

すべての資料の確認の結果, 1995 年に発行され た［雑誌］『産業と環境』に,サフィア・ミニーが 書いた「フェア・トレード—“貿易”を通して参加 する「持続可能な社会」づくり」が日本で初めて 発行されたフェアトレードについての出版物と言 える。この中でサフィア・ミニーは，世界中で進 む貿易の自由化は一部の人々には利益をもたらす が，他の人々と未来世代を犠牲にしており，南北 
表 1 「フェアトレード」をキーワードに国立国会図書館リサーチで検索した出版物の推移（検索日： 2014 年 7 月 4 日)

注）重複しているものが 9 件あったので，重複分を除いて 9 件分の出版物として扱っている。 *印は，本稿で扱っているフェアトレードについての記述でない。

\begin{tabular}{|c|c|c|c|c|c|c|c|c|c|c|c|c|}
\hline & 図書 & 記事・論文 & 新聞 & 博士論文 & 雓誌 & 映像資料 & 政府刊行物 & 立法情報 & オンライン資料 & 参考情報 & 分類なし & 総計 \\
\hline 1973 & - & - & - & - & $1^{*}$ & - & - & - & - & - & - & $1^{*}$ \\
\hline 1974 & - & - & - & - & - & - & - & - & - & - & - & - \\
\hline 1975 & - & - & - & - & - & - & - & - & - & - & - & - \\
\hline 1976 & - & - & - & - & - & - & - & - & - & - & - & - \\
\hline 1977 & - & - & - & - & - & - & - & - & - & - & - & - \\
\hline 1978 & - & - & - & - & - & - & - & - & - & - & - & - \\
\hline 1979 & - & - & - & - & - & - & - & - & - & - & - & - \\
\hline 1980 & - & - & - & - & - & - & - & - & - & - & - & - \\
\hline 1981 & - & - & - & - & - & - & - & - & - & - & - & - \\
\hline 1982 & - & - & - & - & - & - & - & - & - & - & - & - \\
\hline 1983 & - & - & - & - & - & - & - & - & - & - & - & - \\
\hline 1984 & - & - & - & - & - & - & - & - & - & - & - & - \\
\hline 1985 & - & - & - & - & - & - & - & - & - & - & - & - \\
\hline 1986 & - & - & - & - & - & - & - & - & - & - & - & - \\
\hline 1987 & - & - & - & - & - & - & - & - & - & - & - & - \\
\hline 1988 & - & - & - & - & - & - & - & - & - & - & - & - \\
\hline 1989 & - & - & - & - & - & - & - & - & - & - & - & - \\
\hline 1990 & - & - & - & - & - & - & - & - & - & - & - & - \\
\hline 1991 & - & - & - & - & - & - & - & - & - & - & - & - \\
\hline 1992 & - & - & - & - & $2^{*}$ & - & - & - & - & - & - & $2^{*}$ \\
\hline 1993 & - & - & - & - & - & - & - & - & - & - & - & - \\
\hline 1994 & - & - & - & - & - & - & - & - & - & - & - & - \\
\hline 1995 & - & - & - & - & 1 & - & - & - & - & - & - & 1 \\
\hline 1996 & - & 2 & - & - & 3 & - & - & - & - & - & - & 5 \\
\hline 1997 & - & 1 & - & - & 3 & - & - & - & - & - & - & 4 \\
\hline 1998 & 1 & 5 & - & - & 11 & - & - & - & - & - & - & 17 \\
\hline 1999 & - & 2 & - & - & 10 & - & - & - & - & - & - & 12 \\
\hline 2000 & 1 & 2 & - & - & 13 & - & - & - & - & - & - & 16 \\
\hline 2001 & 3 & 4 & - & - & - & - & - & - & - & - & - & 7 \\
\hline 2002 & - & 4 & - & - & - & - & - & - & - & - & - & 4 \\
\hline 2003 & 4 & 13 & - & - & - & - & 1 & - & - & - & - & 18 \\
\hline 2004 & 3 & 22 & - & - & - & - & - & 1 & - & - & - & 26 \\
\hline 2005 & 3 & 10 & - & - & - & - & 1 & - & - & - & 2 & 16 \\
\hline 2006 & 1 & 12 & - & - & - & - & - & - & - & - & 1 & 14 \\
\hline 2007 & 8 & 23 & - & - & - & - & 2 & - & - & - & 1 & 34 \\
\hline 2008 & 12 & 18 & - & - & - & - & - & - & - & - & 2 & 32 \\
\hline 2009 & 8 & 41 & - & 1 & - & - & - & - & - & - & 6 & 56 \\
\hline 2010 & 6 & 31 & - & 1 & - & 1 & - & - & - & - & 4 & 43 \\
\hline 2011 & 7 & 15 & - & - & - & - & - & - & - & - & 4 & 26 \\
\hline 2012 & 5 & 25 & - & - & - & - & - & 1 & - & - & 3 & 34 \\
\hline 2013 & 6 & 20 & 1 & 1 & - & 1 & - & 1 & - & - & 5 & 35 \\
\hline 2014 & 1 & 6 & - & - & - & - & - & - & - & - & 2 & 9 \\
\hline 出版年未記載 & - & - & - & - & - & - & - & 3 & 1 & 2 & 12 & 18 \\
\hline 総計 & 69 & 256 & 1 & 3 & 44 & 2 & 4 & 6 & 1 & 2 & 42 & 430 \\
\hline 割合 & $16.0 \%$ & $59.5 \%$ & $0.2 \%$ & $0.7 \%$ & $10.2 \%$ & $0.5 \%$ & $0.9 \%$ & $1.4 \%$ & $0.2 \%$ & $0.5 \%$ & $9.8 \%$ & $100 \%$ \\
\hline
\end{tabular}

格差が拡大していることを指摘し，持続的な発展 と環境の管理をサポートしつつも底辺の人々の生 活を向上させる新たな選択肢として“フェアト レード”を紹介し, 自身が立ち上げたフェアトレー ド／環境・開発教育グループ「グローバル・ヴィ レッジ」の取り組みについても紹介していた。

その後 [雑誌] の発行が増え, 2000 年までに 44 件が発行されたが, そのうち 25 件は一般社団法人
日本知的財産協会が発行する雑誌『知財管理』に 掲載された同協会のフェアトレード委員会の報告 であったので, フェアトレードについて書かれた 論文は 19 件のみであった。[雑誌］は先述のもの を含め 2000 年には 13 冊が発行されたが，それ以 降は発行されていない（表 1)。それと入れ替わる ように 1996 年から [記事・論文］の発行が増え， 2009 年には 41 件が発行されたが，その後は減少 
傾向であった（表 1)。[記事·論文］の内容は, 次 のように経時的に変化していた。初めて [記事・ 論文]の発行のあった 1996〜2002 年頃まではフェ アトレードの取組み・仕組みを紹介するもの（安 田, 1998 ; 阿久沢, 1998 ; 久賀, 山尾, 2001 ; 皆 川, 2002) が多かったが, 発行数が増加した 2003 年以降は生産現場の報告やフェアトレードの意義 や課題についての報告（堀田, 2003; 辻村, 2003) が増加していた。［記事・論文］の発行が初めて 20 件を超えた 2004 年は『農業と経済』第 70 巻第 4 号に特集「新しい農産物貿易ーフェアトレード の可能性を探る (第 1 部フェアトレードのめざす もの；第 2 部 フェアトレードの実像に迫る)」が 組まれ, 14 件が掲載されていた。最も掲載数の多 かった 2009 年も『アジ研ワールド・トレンド』 No.163に特集「フェアトレードと貧困削減」が組 まれ，9件が掲載されていた。一方， 23 件発行さ れていた 2007 年は特定の雑誌の特集はなく, 学術 誌よりも生協の雑誌（中村 2007）など業界誌などに 多く掲載されていた。また, 2006 年以降に企業の社 会的責任 (CSR : Corporate Social Responsibility) の側面からフェアトレードについて分析した報告 (金田 2007 ; Janet and Kirsteen, 2007a ; Janet and Kirsteen, 2007b） が増加していた他, 2009 年以降 には, フェアトレードの歴史（渡未 2009 ; 渡未 2010）やその研究のレビュー（佐藤 2009）, そし てフェアトレードの全国意識調査について研究 （渡辺 2013）が報告されていた。

次に, [図書］の発行数に関しても [記事・論 文と同様に 1998 年に初めてマイケル・バラッ ト・ブラウンの訳本「フェア・トレード : 公正な る貿易を求めて」が発行された後, その発行数は 次第に増え 2008 年に 12 冊が発行されたが, その 後は減少傾向で 2013 年には 6 冊に半減していた （表 1)。[図書］については, 佐藤（2009）が「フェ アトレード研究のためのブックレビュー」に詳し いが，フェアトレードの紹介をするものから，生 産国の現状や問題点を詳細に報告するもの, フェ アトレード事業を展開している人物の手記などが 発行されている。また, 2009 年には望月洋孝によ る初めての [博士論文］「日本におけるフェアト レードの展開とその推進主体に関する研究」が発 行され, 2013 年までに 3 件のフェアトレードを
テーマにした博士論文が発行されている（表 1)。 [博士論文］が初めて発行された 2009 年は, [記 事·論文 $]$ との発行が最も多かった年でもあり，1 年間でフェアトレードに関する出版物が最多の 56 件も発行されていた（表 1 )。つまり, 出版物発 行数の点から見ると, 2009 年が最も活性化してい た年といえる。

\section{2 フェアトレードについての新聞記事掲載数 の推移}

2012 年現在, 日本では 106 紙の新聞が発行され ているが，本稿では全国紙の中で最もフェアト レードについての記事が多く掲載されている朝日 新聞および経済界の動向を報じている日本経済新 聞をその代表とし，朝日新聞の記事が検索可能な 新聞記事オンラインデータベース「聞蔵 II ビジュ アル ${ }^{19)} 」$, 過去 20 年以上の日本経済新聞の記事を 検索可能なデジタルメディア「日経テレコン $\left.21^{20)}\right\rfloor$ にて検索を行った。

\subsection{1「聞蔵 II ビジュアル」での検索結果}

朝日新聞社の「聞蔵 II ビジュアル（朝日新聞 1985〜，週刊朝日・AERA 全文記事データベー ス)」にて「フェアトレード」と「Fair Trade」を キーワードに記事の検索を行ったところ（検索日： 2015 年 1 月 5 日), それぞれ 1,097 件と 1 件の記事 が確認された（図 1)。後者の「Fair Trade」で確 認された記事は, 貿易摩擦についての記事であり, 本稿で扱っているフェアトレードについての記述 はなかったので解析の対象としなかった。前者の 「フェアトレード」で検索をした結果のうち 17 件 は, 大衆誌の記事であったので, 解析からは除い た。その結果 1992 年に 1 件の記事が掲載されてい たが, 内容を確認したところ本稿で扱っている フェアトレードについての記述はなかったので, 1996 年 4 月 22 日に地域面「東京」で掲載された 「NGO ショップ根張る 途上国援助の「ぐらす るーつ」渋谷／東京」が朝日新聞に初めて掲載さ れたフェアトレードの記事であると言える。この 記事では, 草の根貿易専門店「ぐらするーつ」 2 号 店が, 前年の 11 月の 1 号店に続き開店したことを 紹介し，それまで別々の NGO が個々に販売をし ていたフェアトレード商品を初めて一つの店舗で 


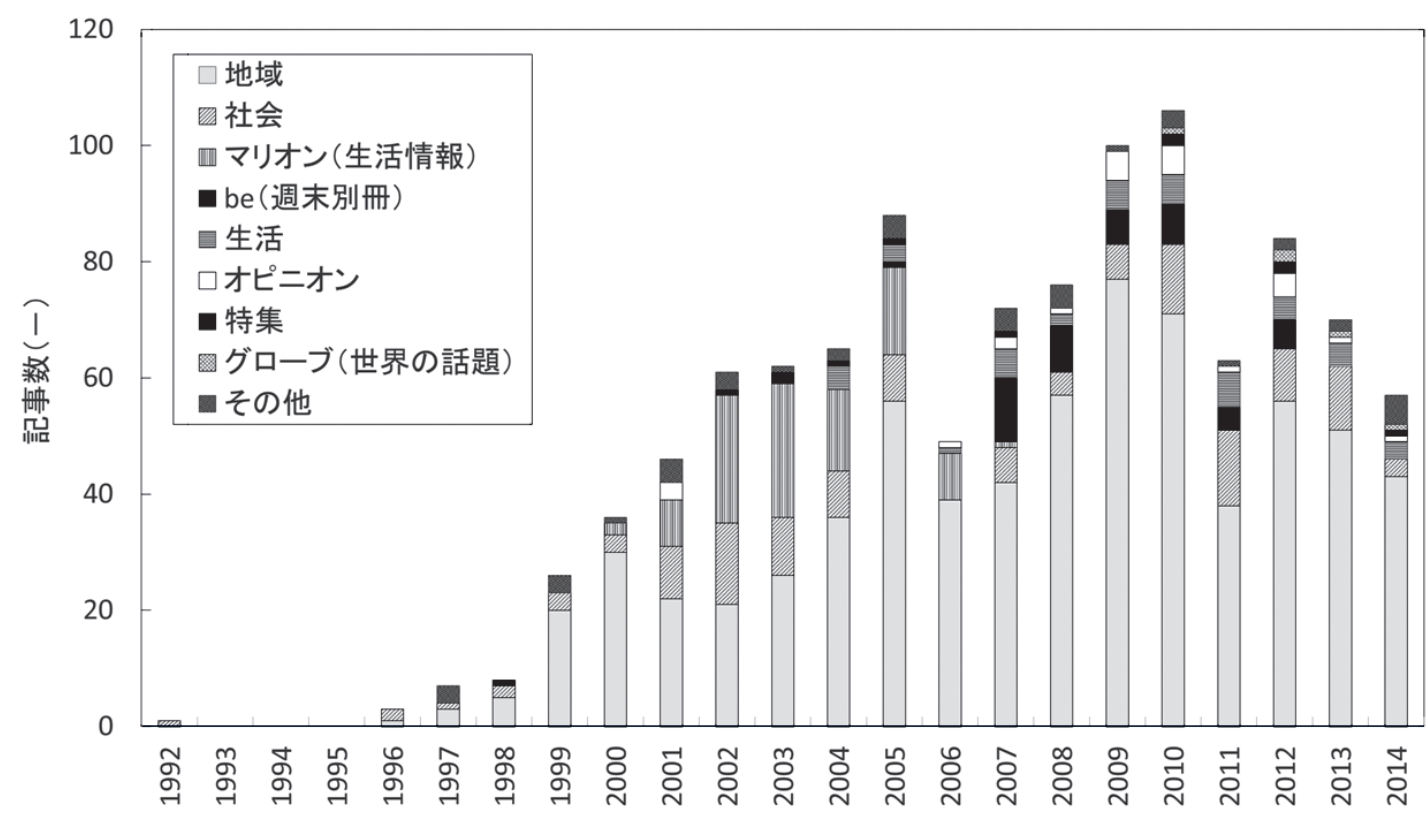

図 1 「フェアトレード」をキーワードに朝日「開く蔵 II ビジュアル」で検索した新聞記事の掲載数の掲 載面別の割合（検索日：2015 年 1 月 5 日）

販売したことで順調に売り上げを伸ばしていると いう内容のほかに，同年 2 月から通信販売を開始 し，5月からは姉妹店「NGO プラザショップ」を 東京 YMCA 国際奉仕センターで始め, 5 月 1 日〜 5 日に「草の根貿易フェスティバル」を開催する という情報が掲載されていた。続いて, 同年 6 月 21 日に朝日新聞の全国版で初めて「小島美佐さん 国際協力ショップ「ぐらするーつ」社長 (ひと)」 とのタイトルで, 同ショップ設立の経緯について 社長の小島美佐を紹介する記事が掲載された。

掲載数は 1999 年以降急激に増加し, 2005 年ま で増加を続け 88 件に達した（図 1)。その後少し 減少したが再度増加し, 最も掲載数の多かった 2010 年には 106 件掲載された。翌年の 2011 年に は 63 件に減少し, 2012 年には 84 件に増加するが その後 2014 年には 57 件と減少していた（図 1)。 掲載された記事を揭載面毎に分けると, 全掲載記 事の $64 \%$ にあたる 695 件の記事が地域面に掲載さ れており, 全国版に掲載されていたのは全掲載記 事の $36 \%$ にあたる 385 件と圧倒的に地域面が多く (図 2), 地域毎のフェアトレード・ショップやイ ベントなどの紹介記事が多く掲載されていた。し かし, 最も掲載数の多かった 2010 年に全国版に掲 載されたフェアトレードの記事は 35 件と約 10 日
に一度の高い頻度であった。

掲載された記事の月ごとの件数を調べると, 年 によって変動はあるが, 5 月に最も多く, 次いで 2 月，11月に多くの記事が掲載されていた（図 3)。 これは「世界フェアトレード・デー ${ }^{21)} 」(5$ 月の第

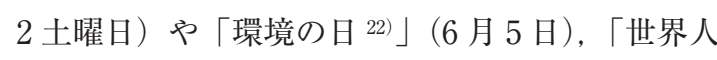
権デー ${ }^{23)} 」(12$ 月 10 日) などの国際的な記念日な どに伴い開催されるイベントや，日本ではチョコ レートを贈る習慣のあるバレンタインデー（2 月 14 日)が影響しているのではないかと予測される。 実際に見出しに「チョコ」という言葉が使われて いた記事は 42 件あったが，その $62 \%$ にあたる 26 件は 2 月に集中しており, 2012 年 2 月 12 日の「鹿 児島全県・1 地方」に揭載されていた「バレンタ インに「フェアトレード」いかが 途上国支援に も鹿児島の雑貨店／鹿児島県」には, フェアト レードチョコレートを販売する店舗の紹介と共 に，バレンタインデー用にフェアトレードチョコ レートを贈ってみてはという提案がされていた。

揭載された記事の内容は次のように経時的に変 化していた。フェアトレードについての記事が初 めて掲載された 1996〜 1998年の 3 年間は記事数が 10 件 /年以下（合計 18 件）と少なかったが, そ の半分 (9 件) が地域面に掲載されており，主に 


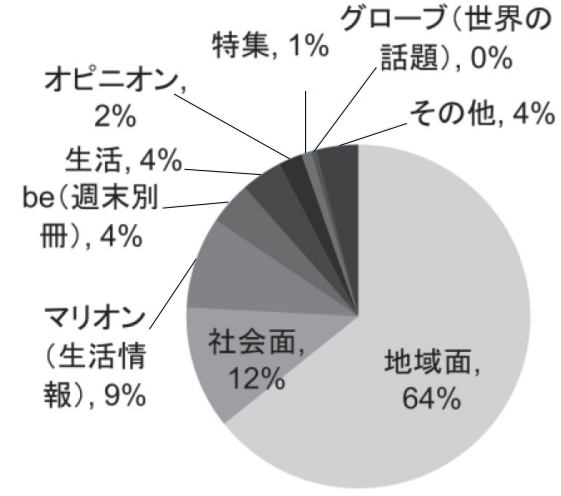

図 2 「フェアトレード」をキーワードに朝日「開 く蔵 IIビジュアル」で検索した新聞記事の掲 載数の掲載面別の割合（検索日：2015 年 1 月 5 日）

フェアトレードに関わる人物・ NPO ・店舗の出店 情報の記事であった。その後 1999 年以降急激に記 事数が増加するがその多くが地域面に掲載されて おり，主な内容はフェアトレードについて消費者 に伝えるためのイベントやシンポジウム, 途上国 支援の活動の告知を兼ねたフェアトレードの紹介 記事などであった。その中でも, 2000～2007 年は, イベント情報, 生活情報のコラムを紹介している 「マリオン」に 93 件の記事が掲載されていた。2008 年以降は「マリオン」への掲載はなくなったが, 2004 年以降は毎年生活面に記事が掲載されてい た。また, 2001 年に 3 件, 2006〜2014 年は毎年才 ピニオンに,「記者有論」や読者投稿欄「声」など で, フェアトレード商品を購入することにより児 童労働や貧困削減貢献できるという仕組みや意味 の説明と, それらの購入を呼びかける記事が掲載 されていた（合計 24 件)。例えば, 2012 年 7 月 18 日の「オピニオン $2 」 に$ 掲載されていた「(記者有 論）グリーン経済 自分の身近なところから 神 田明美」には,「国連持続可能な開発会議（リオ+ 20)」にて資源の消費をおさえて環境を保全しなが ら成長も両立させる「グリーン経済」への移行に ついて話し合われたことを紹介したのち，消費者 が地球規模の視野で関心を持ち「レインフォレス

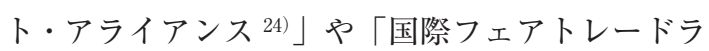
ベル機構」,「MSC」（水産資源を乱獲せず生態系 に悪影響を与えないよう捕られた魚に付けられる 認証）などのマークがついたものを消費者が購入

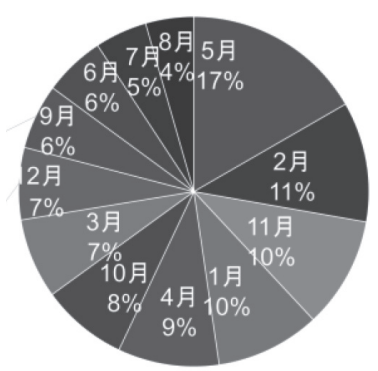

図 3 「フェアトレード」をキーワードに朝日「開 く蔵 IIビジュアル」で検索した新聞記事の月 別掲載数（検索日：2015 年 1 月 5 日）

することで，ビジネス界の環境への配慮や途上国 の貧困改善の取り組みを支え, グリーン経済への 移行を後押しできるということを説明していた。 また, 2013 年 3 月 27 日の「オピニオン $1 」 に$ に掲載 されていた「(記者有論) フェアトレード 貧困な くすチョコ選ぼう 神田明美」には, フェアトレー ド商品は通常より值段が高くなるが, 生産や流通, 消費にかかわる人々がそれぞれ少しずつ意識を向 けそれを選ぶ人が増えることで，ゴールであるよ く見かける商品の裏側にある児童労働や貧困など の問題がなくなるということを説明していた。 2011 年以降には, 2011 年 3 月 11 日に発生した東 日本大震災の支援をフェアトレードショップや NPO が行った記事やフェアトレードの仕組みを 利用して被災地支援をしょうという記事が増加し たほか, 持続可能な社会についての連載記事など の中でフェアトレードショップを営む人々が紹介 されていた。2011年 5 月 13 日の「オピニオン $1 」$ に掲載された「(私の視点) 震災復興支援フェア トレードの活用を 渡辺龍也」では，東日本大震 災の被災地の復興を, 中長期的, 持続的に復興を 支援する仕組みとして「フェアトレード」の仕組 みを活用することを提案していた。

\subsection{2「日経テレコン 21」での検索結果}

次に，日本経済新聞データベース「日経テレコ

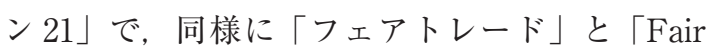
Trade」をキーワードに検索を行ったところ（検 


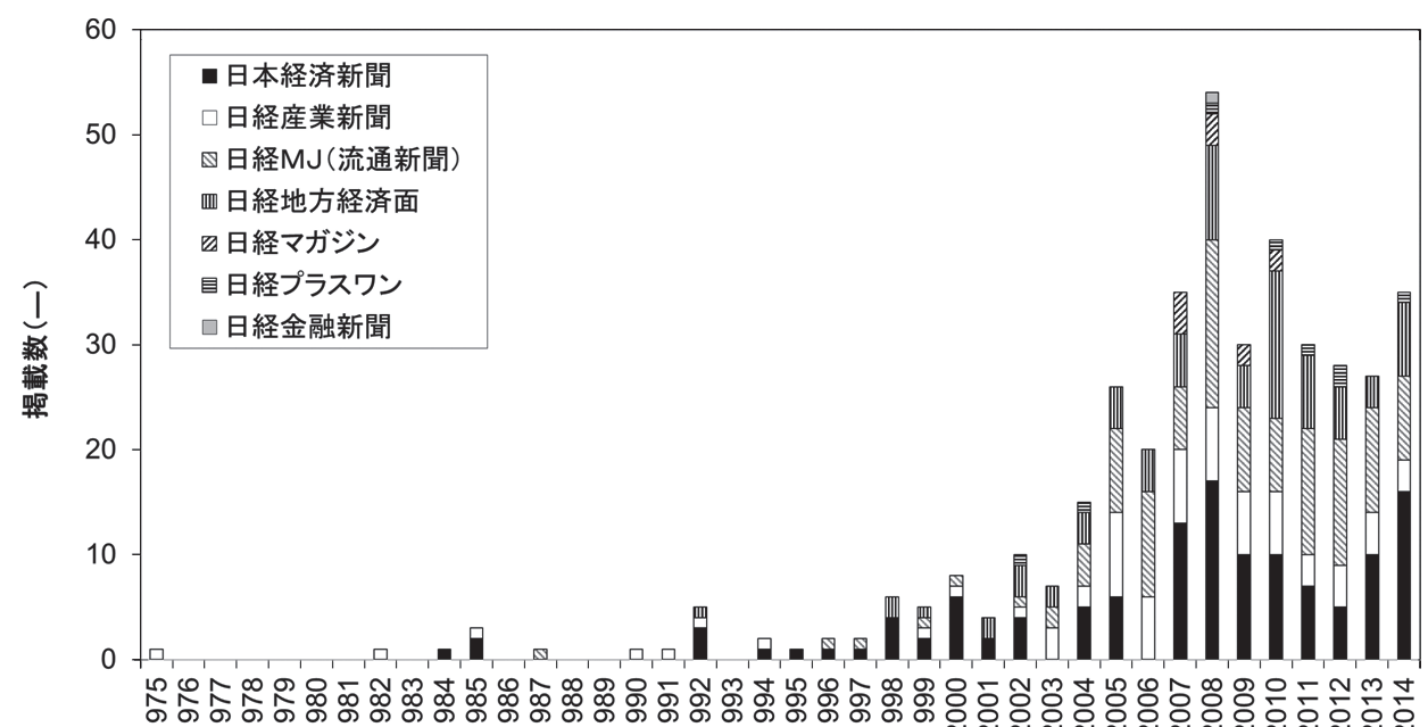

図 4 「フェアトレード」をキーワードに「日経テレコン」で検索した新聞記事の掲載数の推移 （検索日：2015 年 1 月 5 日）

索日:2015 年 1 月 5 日), それぞれ, 398 件と 3 件 の記事が確認された(図 4)。1994 年より前に掲載 されている 13 件の記事は本稿で扱っているフェ アトレードについての記述ではなかったので, 1994 年 2 年 18 日の日本経済新聞 (夕刊) に掲載 された「フェアトレード運動すそ野広がる, 買い 物で国際貢献一途上国の農家応援。」という記事 が, 日本経済新聞社が発行する新聞に初めて揭載 されたフェアトレードに関する記事である。この 記事では,「第 3 世界ショップ」を核にコーヒーや 手芸品のフェアトレードの輸入・販売事業を展開 している「プレスオルターナティブ」とフィリピ ン・ネグロス島のバナナと黒砂糖のフェアトレー ドに取り組んでいる「オルター・トレード・ジャ パン」, そしてコーヒー輸入・焙煎業の「第一コー ヒー」など, フェアトレードを手がける組織・企 業が続々と登場してきていることが紹介されてい た。その後, 掲載される記事数は緩やかに増加し 続け, 2005 年には 26 件, 2008 年には最多の 54 件 が掲載されていたが, 朝日新聞社と同様に 2009 年 には 30 件に減少し, 2010 年に 40 件掲載されたが, 2013 年度には 2008 年の半分の 27 件に減少してい た（図 4)。

日本経済新聞社が発行する新聞は 7 種類ある が,「日経マガジン」(日本経済新聞朝刊別冊),「日
経プラスワン」(生活情報週刊紙),「日経金融新 聞」（金融専門紙）の 3 紙は，それぞれ 11 件，8 件, 1 件とほとんど掲載されていなかった。残り の 4 紙には,「日本経済新聞」(経済紙)に 122 件 (31\%),「日経 MJ (流通新聞)」(消費と流通, マー ケティング情報に特化した専門誌。MJは Marketing Journal の略。）に108件（28\%)，「日 経地方経済面」(日本経済新聞の地方経済面を収 録)に 75 件 $(19 \%)$,「日経産業新聞」(産業・企 業情報に特化した専門紙）に 64 件（17\%）の順に 掲載されていた (図 5)。掲載された記事の月ごと の件数を調べると， 6 月と 9 月が 39 件と 38 件と 少し他の月に比べて多く, 7 月と 8 月が 25 件と 23 件と少ないものの, 他の月は同程度に掲載されて いた（図 6)。

掲載された記事の内容は次のように経時的に変 化していた。フェアトレードについての記事が初 めて掲載された 1994〜2001年の8 年間は記事数が 6 件 /年以下（合計 18 件）と少なかったが, フェ アトレードに関わる人物・NPO ・店舗の紹介の記 事だけでなく, 5 回にわたる連載記事「第 154 話 進め草の根貿易」(2000 年 1 月「日本経済新聞」夕 刊）が揭載され，フェアトレードの日本における 現状や生産地の事情, 課題が紹介されていた。2002 年以降は記事数が増加したが, フェアトレードに 


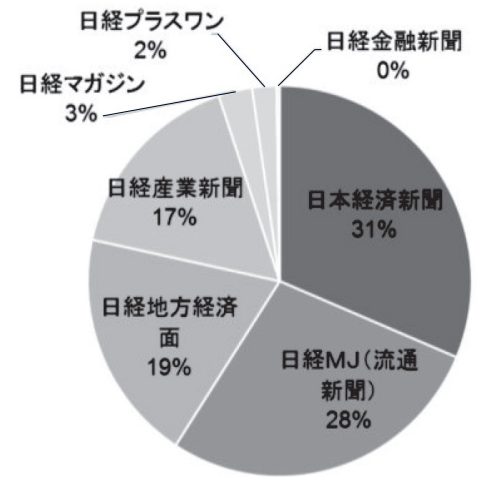

図 5 「フェアトレード」と「Fair Trade」をキー ワードに「日経テレコン」で検索した新聞記 事合計掲載数の掲載紙別の割合 (検索日:2015 年 1 月 5 日)

但し, 本稿で扱っているフェアトレードにつ いての記述でない 1993 年以前の記事は除く。

関するシンポジウムやイベント紹介の記事はほと んどなく，フェアトレードに関わる人物・NPO ・ 店舗の取組の紹介に加え, 新たなフェアトレード 商品の紹介, 企業の企業の社会的責任 (CSR) や 社会貢献の取り組み紹介の記事が増加していた。 イベントを紹介する記事は全記事の中で合計 15 件しか確認されず，その内容も国際フェス夕の紹 介が 2 件と LOHAS についてのシンポジウム 1 件 の他は, 芸術展や企業が参加するフォーラムや経 営力七ミナーの中でフェアトレードが紹介される という内容で, 主にフェアトレードに特化したイ ベントの案内ではなかった。2007 年以降にはフェ アトレードの販売側ではなく, 消費者の意識の変 化, 特に社会貢献につながる消費を選ぶ人が増え てきたという記事が増加していた。実際に見出し に「消費」という言葉が使われていた記事は, 27 件あったがそのうちの $92 \%$ に当たる 25 件は 2007 年以降に掲載されており, 2008 年 2 月 8 日の「日 本経済新聞」に掲載された「消費超流 (4) 社会と の「つながり」追求一参加する満足買う (終)」で は, CSRへの関心が高まる中で, 消費の現場にも 社会的な意義を見いだせるかどうかを判断基準と する「社会的責任消費 (SRC)」が広がっているこ とが紹介されていた。さらに, 同じく見出しに「貢 献」という言葉が使われていた記事は 35 件あった が, その 74\%にあたる 21 件が 2007〜2014 年に掲

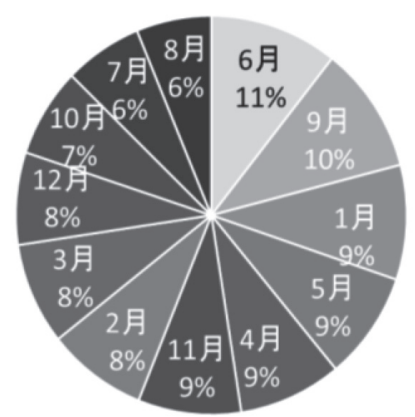

図 6 「フェアトレード」をキーワードに「日経テ レコン」で検索した新聞記事の月別掲載数 (検索日：2015 年 1 月 5 日)

但し，本稿で扱っているフェアトレードにつ いての記述でない 1993 年以前の記事は除く。

載されており，2010年までは「国際貢献」という 言葉が使われていたが, 2011 年以降は「社会貢献」 という言葉に変わっていた。

\section{3. 考察}

\section{1 出版物と新聞報道の変遷からみた社会的動向} 前述のように, 出版物は 1995 年, 朝日新聞社・ 日本経済新聞社の発行する新聞への記事の掲載は それぞれ，1996 年，1994 年に揭載されていたこと から, 日本では 1994〜1996 年からメデイア等を通 した広報が始まったと言える。これは，日本でフェ アトレードが始まった 1974 年から約 20 年後で あった。次に, 出版物発行数, 朝日新聞社・日本 経済新聞社の発行する新聞への記事の掲載件数の 推移から，メディア等を通して広報が多く行われ た年は2008〜2010年と言えるであろう。この点は, 本研究で初めて明らかになった。これは, フェア トレードをテーマにしたドキュメンタリー映画 「おいしいコーヒーの真実」25) が日本で初めて公 開・販売された時期（日本での公開日：2008 年 5 月 31 日, DVD 販売: 2008 年 12 月）とも重なって おり，最も関心が高まっていた時期と言える。渡 辺（2013）によると 2008 年より, フェアトレード や倫理的消費に関する全国調査が盛んに行われる ようになっている。その皮切りになった「平成 19 年度国民生活選好度調査 ${ }^{26)} 」$ は, 「近年の経済・社 
表 2 大学入試センター試験問題の中に「フェア トレード」または「fairtrade」という言葉 が登場した年度と科目, 登場箇所

\begin{tabular}{|c|c|c|}
\hline 年度 & 科目 & 登場箇所 \\
\hline 2009 & 英語(筆記) & 第3問, C(設問テーマ) \\
\hline 2010 & 現代社会 & 第3問, 問3, 回答番号34, 選択肢(4) \\
\hline 2011 & - & - \\
\hline 2012 & 現代社会 & 第1問, 問1, 回答番号1, 選択肢(2) \\
\hline 2013 & 現代社会 & 第1問, 問5, 回答番号7, 選択肢(3) \\
\hline 2014 & 倫理 & 第1問(設問テーマ) \\
\hline
\end{tabular}

“大学入試センター試験問題から筆者作成

会システムの変化や価值観の多様化に伴う国民の 意識及び行動様式」をテーマとして実施され，消 費生活に関する知識量を表す「消費者力」と商品 やサービスの選択時に企業の社会貢献を意識して 選択しているかどうかという「社会的価值行動」に ついて調べられ, その結果は「平成 20 年度版国民 生活白書」(内閣府, 2008) 27 にも掲載されている。 国民生活選好度調査とは, 社会経済環境が変化す る中で，国民が日常生活でどのような意見を持っ ているのか調べ政策運営の基礎資料とするために 内閣府により実施されているものである。このこ とは，消費者のフェアトレードへの関心が高まっ ていることを各調査機関が認識していたことの表 れであろう。

さらに, 2009 年には大学入試センター試験の試 験問題の中に初めてフェアトレードという言葉が 登場し, その後 2011 年を除いて毎年登場している (表 2)。2010 年, 2012 年, 2013 年は回答の選択肢 として示されているだけであったが, 2009 年の 「英語」では設問のテーマとして「世界初のフェア トレードの町」であるイギリスのガースタング町 が紹介され, 2014 年の「倫理」では設問にフェア トレードコーヒーを買う大学生の会話が出題され ていた。大学入試センター試験は, 高等学校段階 における基礎的な学習の達成の程度を判定するこ とを主たる目的とするものであるので ${ }^{28)}$, 進学率 98.5\%（2015 年 5 月 1 日現在） 29) である高等学校 における基礎的な知識の一つとしてフェアトレー ドが認識されるようになってきていると言える。

日本でフェアトレードのメディア等を通した広 報が始まった時期に, 国際的には国際コーヒー価格 の大暴落, いわゆる「コーヒー危機」(第一次:1989 ～1992 年, 第二次 1990 年代末～ 2005 年, 2002 年
には国際コーヒー価格が過去 100 年で最低を記録) が発生し (妹尾, 2009), フェアトレードコーヒー への関心が世界的に高まっていたと予測される。

また，同時期にはフェアトレードを広めるため に3つのキャンペーンが世界中で展開されている。 一つ目が1996年にフェアトレード専門店のネット ワーク団体である NEWS! によりヨーロッパで開 催された「欧州世界ショップデー」である（長坂, 2008b)。これは, 2002 年以降, 国際的なイベント となり，「世界フェアトレード・デー（World Fair Trade Day)」として 5 月の第 2 週の週末に世界中 でフェアトレードをアピールするイベントが行わ れている (長坂, 2008b)。日本では, 1999 年にグ ローバル・ヴィレッジ/ピープル・ッリーが日本 国内のフェアトレード・ショップに呼びかけて約 100 軒が参加したのがはじまりで, その後毎年開催 されている ${ }^{30)}$ 。日本で世界フェアトレード・デー が開催され始めた 1999 年以降に, 朝日新聞にフェ アトレードについて消費者に伝えるためのイベン トやシンポジウムの記事が急増していたことから も，この影響が大きいものと予測できる。二つ目 が 2002 年 4 月にオックスファム・インターナショ ナル 31) により開始された「メイク・トレード・フェ ア (Make Trade Fair)」で, 政府, 各種機関, 多 国籍企業を対象に貿易の正義と公正な貿易を目的 に, キャンペーンが行われている。三つ目は, 先 述のセンター試験の設問にもなった 2000 年 4 月に イギリスのガースタング町で始められた「フェア トレード・タウン (Fair Trade Town)」である。 フェアトレードタウンは, 市民, 行政, 企業, 小 売店, 学校など街全体でフェアトレードを応援す る市町村, 群, 県などの自治体のことで, 現在で は世界 22 カ国, 1,000 以上の自治体がフェアトレー ドタウンとして認証されている。日本でも, 2011 年 4 月, フェアトレードタウン運動を推進し認定 する母体として「一般社団法人フェアトレード夕 ウン・ジャパン」が設立され，2011 年 6 月には, 熊本市が日本初, アジア初のフェアトレードタウ ンとして認定された ${ }^{32)}$ 。渡辺（2013）は, フェア トレードタウン運動が盛んな都市は全国平均に比 ベ，フェアトレードの認知率が高いことを指摘し ており, キャンペーンの効果が表れていると言え る。このような世界的なフェアトレードキャン 
表 3 世界のフェアトレード認証製品推定市場規模に占める日本の推定市場規模の割合と, 日本の小売 市場規模に占めるフェアトレード認証製品推定市場規模の割合の推移

\begin{tabular}{|c|c|c|c|c|c|c|c|}
\hline 年 & $\begin{array}{l}\text { (a)世界のフェアト } \\
\text { レード認証製品推定 } \\
\text { 市場規模 }^{*}(€)\end{array}$ & $\begin{array}{l}\text { (b)日本のフェアト } \\
\text { レード認証製品推定 } \\
\text { 市場規模 }^{*}(€)\end{array}$ & $\begin{array}{c}\text { 世界のフェアトレード } \\
\text { 認証製品推定市場規模 } \\
\text { に占める日本の推定市 } \\
\text { 場規模の割合b/a×100 } \\
(\%)\end{array}$ & $\begin{array}{l}\text { 為替 } \\
\text { レート } \\
(€ / 円)^{\star \star}\end{array}$ & $\begin{array}{l}\text { (c)日本のフェア } \\
\text { トレード認証製品 } \\
\text { 推定市場規模 } \\
\text { (億円) }\end{array}$ & $\begin{array}{l}\text { (d)日本の小 } \\
\text { 売市場規模 } \\
\text { (億円) }\end{array}$ & $\begin{array}{l}\text { 日本の小売市場規模 } \\
\text { に占めるフェアト } \\
\text { レード認証製品推定 } \\
\text { 市場規模の割合 } \mathrm{c} / \mathrm{d} \times \\
100(\%)\end{array}$ \\
\hline 1997 & $259,720,000$ & - & - & - & - & - & - \\
\hline 1998 & $289,130,000$ & - & - & - & - & - & - \\
\hline 1999 & $334,950,000$ & - & - & 121.35 & - & - & - \\
\hline 2000 & $397,500,000$ & - & - & 99.29 & - & - & - \\
\hline 2001 & $486,480,000$ & - & - & 108.75 & - & - & - \\
\hline 2002 & $588,090,000$ & - & - & 118.01 & - & - & - \\
\hline 2003 & $832,970,000$ & - & - & 130.84 & - & - & - \\
\hline 2004 & $831,523,066$ & $2,500,000$ & 0.30 & 134.34 & 3.4 & 370,007 & 0.001 \\
\hline 2005 & $1,132,400,000$ & $3,400,000$ & 0.30 & 137.07 & 4.7 & 359,645 & 0.001 \\
\hline 2006 & $1,623,000,000$ & $4,100,000$ & 0.25 & 145.90 & 6.0 & 348,196 & 0.002 \\
\hline 2007 & $2,381,127,046$ & $6,200,000$ & 0.26 & 161.17 & 10.0 & 344,515 & 0.003 \\
\hline 2008 & $2,954,368,443$ & $9,567,132$ & 0.32 & 151.40 & 14.5 & 347,541 & 0.004 \\
\hline 2009 & $3,443,412,599$ & $11,283,451$ & 0.33 & 129.99 & 14.7 & 360,614 & 0.004 \\
\hline 2010 & $4,319,039,047$ & $14,434,289$ & 0.33 & 116.26 & 16.8 & 368,651 & 0.005 \\
\hline 2011 & $4,984,043,861$ & $59,327,333$ & 1.19 & 110.94 & 65.8 & 380,324 & 0.017 \\
\hline 2012 & $4,786,772,862$ & $71,419,147$ & 1.49 & 102.52 & 73.2 & 378,860 & 0.019 \\
\hline 2013 & $5,500,317,789$ & $68,976,524$ & 1.25 & 129.58 & 89.4 & - & - \\
\hline
\end{tabular}

* Fair Trade International Annual Report 2003-04, 2004-05, 2005-06, 2006-07, 2007, 2008-09, 2009-10, 2010 Financials and Global Sales Figures, Fairtrade International Annual Report, 2011-12, 2012-13, 2013-14より引用。

** Prof. Werner Antweiler at UBC's Sauder School of Business, PACIFIC Exchange Rate Service, Foreign Currency Units per 1 European Euro,1999-2013 (http://fx.sauder.ubc.ca) より引用。

*** 総務省 $(2014)$ 「平成26年版 情報通信白書」より引用。

ペーンに参加する形で, 日本でもフェアトレード が広がってきており，それに伴ってメディアを通 じた広報も増加してきていたことが伺える。

\section{2 倫理的, 社会貢献的な企業活動との一体化}

次に, 出版物の数では 2009 年, 朝日新聞社, 日 本経済新聞社発行の新聞への掲載記事数ではそれ ぞれ, 2010 年, 2008 年をピークにその後, 減少し ている点に注目したい。この間のフェアトレード 製品の売り上げとの関係を探るため, 世界のフェ アトレード認定製品推定市場規模に占める日本の それの経年変化と, 日本の小売市場規模に占める 日本のフェアトレード認定製品推定市場規模の変 化について調べた（表 3）。その結果, 2004～2013 年の 10 年間で世界のフェアトレード認定製品推 定市場規模は, 83.2 億 $€$ から 6.6 倍の 550 億 $€$ に 増加していた。同期間における日本のフェアト レード認定製品推定市場規模は, 3.4 億円から約 26 倍の 89.4 億円に増加しており, 世界のフェアト レード認定製品推定市場規模に占める日本の割合 は 0.3\%から $1.25 \%$ に増加していた。また, 出版物 数, 掲載件数が減少していた 2008 年から 2012 年 の 4 年間について, 日本の小売市場規模は 348 千億
円から 379 千億円と 1.1 倍しか増加しておらず横 ばいだったにも関わらず，その間の日本のフェア トレード認証製品の推定市場規模は 14.5 億円から 73.2 億円の約 5 倍に増加し, 日本の小売市場規模 に占める日本のフェアトレード認定製品推定市場 規模の割合は $0.004 \%$ から $0.019 \%$ へと約 5 倍に増 加していた（表 3)。また, 渡辺（2013）によると フェアトレードという言葉を聞いたことがある人 の割合（知名度）は, 2008 年から 2012 年で $42.2 \%$ から 50.3\%へ，フェアトレードを貧困／環境問題 と関連付けられる人の割合（認知率）は， $22.7 \%$ から $25.7 \%$ へとい゙れも上昇している33)。このこ とから，フェアトレードに関する社会的関心が低 下したわけではなく, フェアトレードと関連した 別の事象に注目が移り変わった可能性が考えられ た。実際に日本経済新聞社発行の新聞には, 2007 年以降社会貢献につながる消費を選ぶ人が増えて きたことを紹介する記事が増加していたが, 近年 このような「エシカル消費」や「ソーシャルビジ ネス」に社会的な注目が集まっていることから, これが影響している可能性が考えられる。ここで 「エシカル (ethical, 倫理的, 道徳上) 消費」とは 環境保全や社会貢献などを促進することにつなが 


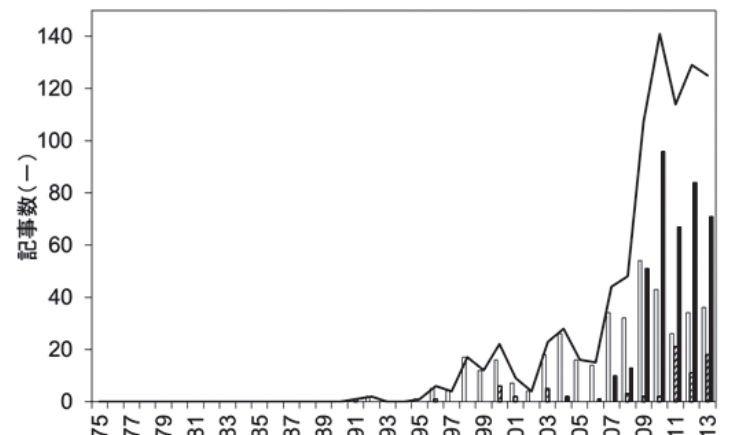

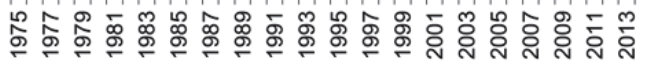

（II）聞く蔵 Iビジュアル(検索日:2015年1月5日)

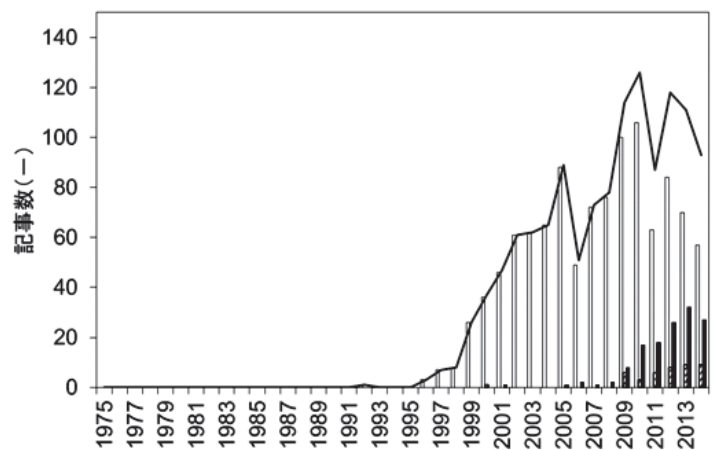

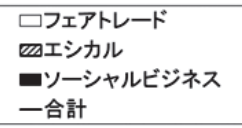

（III）日経テレコン(検索日:2015年1月5日)

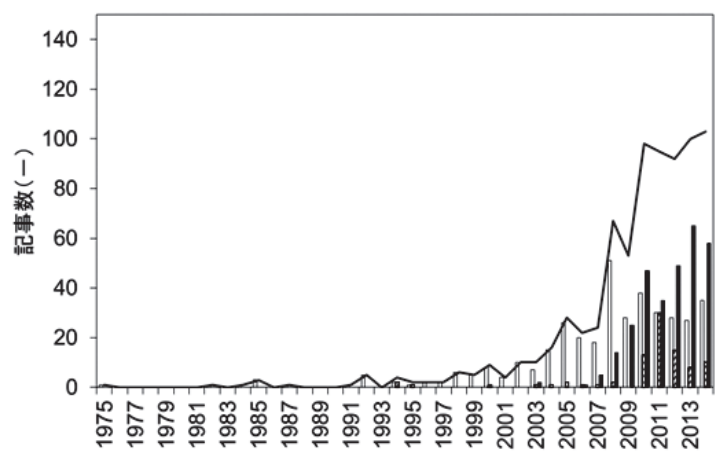

図 7 「フェアトレード」,「エシカル」,「ソーシャルビジネス」をキーワードに（I）国立国会図書館リサー チ,（II）聞く蔵 IIビジュアル，（III）日経テレコンにて検索した出版物・新聞記事の掲載数の推移

る消費のことで，フェアトレードもこれに含まれ ている。また,「ソーシャルビジネス」とは, 地域 社会の課題解決に向けて, 住民, NPO, 企業など, 様々な主体が協力しながらビジネスの手法を活用 して取り組む新しいビジネスのことで ${ }^{34)}$, フェア トレードのような途上国の支援も範疇として含ま れている。実際に, 2011 年 6 月 28 日の日経産業 新聞には, 環境保護活動の支援や貧困問題の解決 を目的としたレインフォレスト・アライアンス認 証取得の茶葉を使用した紅茶やアグロフォレスト リー35)で栽培されたチョコレートの新製品が増加 していることを紹介する記事が掲載されていた。 そこで,「国立国会図書館リサーチ」,「聞蔵 II ビジュアル」と「日経テレコン $21 」$ のデータベー ス上で,「エシカル」,「ソーシャルビジネス」を キーワードに検索を行った。その結果を「フェア トレード」のそれと比較したところ, 全てのデー
タベースで,「エシカル」はそれぞれ 2011 年, 2009 年, 2010 年,「ソーシャルビジネス」はそれぞれ 2009 年, 2009 年, 2008 年以降に急増しており（図 7)，それらの合計は，横ばいまたは増加していた。 これらのことから, フェアトレードへのメディア の関心は 2008〜2010 年をピークに低下したわけ ではなく，「エシカル」や「ソーシャルビジネス」 などの新たな事業にフェアトレードが包含されて 伝えられるようになったと考えられた。一例を示 すと, 2012 年 2 月 27 日の日本経済新聞の記事 「ソーシャルビジネス, 担い手は 20～30 代, 活動 に厚み増す。」では，障害者就労支援やフェアト レードに取り組む宝飾店など, 福祉や貧困などの 社会的課題を, 事業を通じて解決するソーシャル ビジネスに取り組む 20３0 代の若手経営者が増 えていることを大きく紹介している。さらに, 2014 年 5 月 22 日の朝日新聞の記事「エシカル, 日本で 
も機運 服づくり, 環境配慮や社会貢献」では, エシカルファッションが日本でも広まってきたこ とを紹介しており，この中で「エシカル ファッ ション ジャパン」が揭げる取組み例として「不 当な労働と搾取をなくす」,「地域に根ざす物作り」 などが挙げられており，これはまさにフェアト レードの概念と一致している。このように, フェ アトレードは倫理的で社会貢献につながる消費活 動の一つとして（一体化して）伝えられるように なってきていることが明らかになった。これは, 渡未（2013）によるフェアトレードの普及が, 途 上国における持続可能な発展と環境保全に貢献す るだけではなく，先進国の環境配慮型生活への転 換をもたらすという指摘とも一致している。

それぞれの発行物数と記事の揭載傾向は次のよ うに経時的に変化していた。「国立国会図書館り サーチ」での検索の結果,「エシカル」についての 出版物は 92 件確認された。そのうち 5 件は出版年 が不明であったが, 出版年が明らかな 87 件のうち 2007 年以前に発行されていたのは 17 件のみで (もっとも古いものは 1930 年), 2011 年以降にそ の数は急増していた（図 7-I）。また, 2007 年以 前の出版物は心理学に関するものが多かったが, 2008 年以降の出版物は主に本稿の対象にしてい る消費と関連した内容のものであった。また，全 出版物のうち $57 \%$ にあたる 52 件は [記事・論文] で, 17\%にあたる 16 件が [図書] であった。最も 出版物が多く発行された 2013 年には雑誌『環境会 議』が特集「合言葉はソーシャル $\times$ エシカル 社会 のためになる消費」を組み，新しい消費の在り方 などについての論文が 5 件が掲載されていた。続 いて「ソーシャルビジネス」についての出版物は, 499 件確認された。そのうち 22 件は出版年が不明 であったが, 出版年が明らかな 477 件中 2007 年以 前に出版されていたのは 13 件のみで (もっとも古 いものは 2004 年), 2009 年以降にその数は増加し ていた（図 7-I）。また, 全出版物のうち $59 \%$ に あたる 283 件は［記事・論文］で，20\%にあたる 98 件が [図書] であった。出版物が増加した 2009 年には雑誌『保健の科学』に特集「保健医療福祉 領域の社会企業家のはたらき」が組まれ 7 件が発 行されていた。その後, 社会企業家の紹介をする 本や論文が増加し， 2014 年には雑誌『地域開発』
に特集「震災復興と NPO, 社会企業家」が組まれ 10 件が揭載されていた。

次に,「聞蔵 II ビジュアル」で「エシカル」に ついて検索した結果，39件の記事が確認された。 記事は 2000 年に掲載された 1 件を除き, 2009 年 以降に揭載され，年々増加していた（図 7-II）。 全記事のうちの 38\%に当たる 15 件はイベントの 案内であった。また，全記事の $46 \%$ に当たる 18 件はファッションについての記事で, エシカル ジュエリーやフェアトレードの衣料の紹介がされ ていた。2012 年以降は, エシカルな活動に取り組 むファッションデザイナーの紹介記事が増加して いた。続いて「ソーシャルビジネス」について検 索した結果，133 件の記事が検出された。2001 年 に初めての記事が掲載されていたが，それ以降 2008 年までに揭載された記事は 5 件のみで, 2009 年以降に記事数は急増していた (図 7-II)。また, 全記事のうちの $21 \%$ にあたる 29 件がイベントの 案内であったが，それよりもソーシャルビジネス の取組み紹介の記事が多く掲載されていた。たと えば 2014 年 5 月 18 日に発行されたグローブ 135 号には,「私の起業で未来を変える」という特集が 組まれて，7面に渡り 8 件の記事が掲載され，海 外事情を含め起業について詳しく紹介されてい た。また 2011 年以降は同年発生した東日本大震災 の復興に関する記事が毎年掲載されていた。

最後に,「日経テレコン 21」で「エシカル」に ついて検索した結果，84 件の記事が検出された。 1994 年に初めての記事が掲載されていたが, それ 以降 2009 年までに揭載された記事は 12 件のみで, 2010 年以降に記事数は急増していた（図 7-III）。 イベントの案内などの記事は少なく，商品紹介の 記事が多く掲載されていた。また, 「聞蔵 II ビジュ アル」と同様，特にファッションについての記事 が多く, 全記事の $26 \%$ に当たる 22 件がそうであっ た。2011年は東日本大震災の支援に関する記事が 目立ったが, 2012 年以降はファッションの記事が 増加していた。続いて「ソーシャルビジネス」に ついて検索した結果, 301 件の記事が検出された。 2003 年に初めての記事が揭載されていたが，それ 以降 2007 年までに掲載された記事は 16 件のみで, 2008 年以降に記事が増加していた（図 7-III）。記 事の内容は主に, ソーシャルビジネスの取組み紹 
( I )あなたがフェアトレードを知ったきっかけを教えて下さい

(複数回答可)。

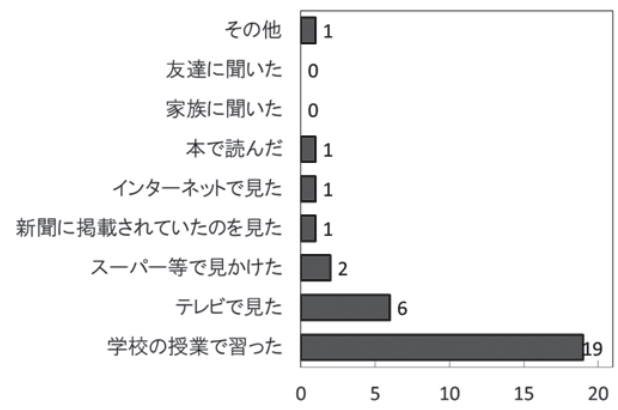

（ II )フェアトレードについての認識や行動について教えて下さい

(複数回答可)。

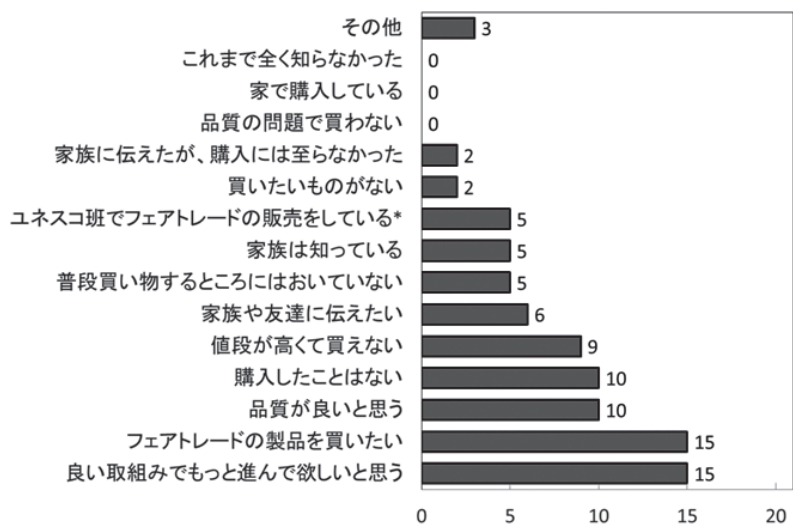

(III)この実習を通してフェアトレードに対するイメージは変わりましたか。どのように変わったか詳しく教えて下さい。 （自由記述の内容を筆者が類似する内容ごとにカカンンした）

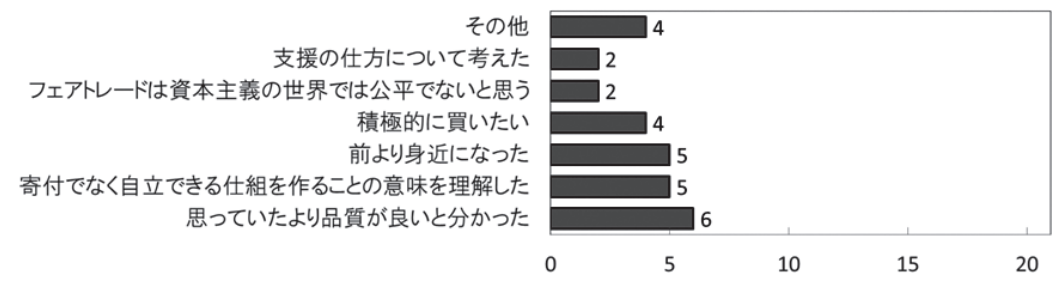

図 8 広島大学附属高等学校 2 年生 21 名を対象に行ったアンケートの結果 （2014 年 12 月 4 日実施，有効回答率 100\%）

*ユネスコ班では，文化祭の際にフェアトレード製品の販売をしている。

介の記事が多く掲載されていた。2007〜2012 年は バングラデシュにあるグラミン銀行を創設したこ とで 2006 年にノーベル平和賞を受賞したムハマ ド・ユヌス氏のインタビュー記事や講演会, 大手 企業のグラミン銀行との合併や財団設立について の記事が多くみられた。2012 年以降は, 企業家支 援セミナーや助成金・融資の情報，そして支援機 関の設立についての記事が増加しており，2013 年 に第 1 回が開催された日本経済新聞社主催の「日 経ソーシャルイニシアティブ大賞」の記事が 1 回 毎に募集, 審査結果の報告, 表彰式など 7 件程度 揭載されていた。また, 2011 年は東日本大震災の 支援についての記事も毎年掲載されていた。

\section{3 フェアトレードの抱える課題}

フェアトレードへの社会的関心が高まっても, それが購入に繋がらなければ意味がない。渡辺 （2013）は,フェアトレードを認知している人（言 葉を認識しているだけでなく「環境」や「貧困」
と結び付けられる）であっても，情報不足や身近 な店舗で購入できないことにより購入に至らない 例が多いということを指摘している。その一例と して，筆者が 2014 年 12 月 4 日に広島大学附属高 等学校 2 年生 21 名を対象に行った平成 25 年度 SSH 事業（基礎枠）「ESD 研究：フェアトレード 実習」の受講者アンケート結果を紹介したい。こ の実習は, 複数のコースが準備されており, 生徒 自らがコースを選択して参加している。実習は 2 週（11月25日, 12 月 4 日）に分けて実施し,フェ アトレードの歴史や仕組みについての講義のほ か, フェアトレード製品を販売している事業者に 商品を借りて模擬販売体験, 貿易ゲーム ${ }^{36)}$ を行っ た。実習後に行ったアンケートの結果, 回答者の 約 7 割の 15 名の生徒が「フェアトレードの製品を 買いたいと思う」と回答したにも関わらず，約半 数の 10 名は購入したことがなく, 5 名が「普段買 い物するところにはおいていない」と回答してい た (図 8-II)。さらに受講者の約 9 割に当たる 19 
名が学校の授業でフェアトレードを知り（図 8I ), 高い興味を持って実習に参加していたが,「こ の実習を通してフェアトレードに対するイメージ は変わりましたか。どのように変わったか詳しく 教えて下さい。」という自由記述欄には 6 名の生徒 が「同情で買うものだと思っていたけど良い物が 売っていると分かった。や「フェアトレードとい うものが具体的にどのようなものかは知らなかっ たので，こんなにたくさん高品質なものがあるの だと知って,欲しくなりました。」など「思ってい たより品質が良いと分かった」という内容の記述 をしており（図 8-III），高い興味を持っていても 実物に触れる機会がなく, 実際にフェアトレード 製品にアクセスできていないということがこの結 果からも伺えた。これは, 対象数が少なく限られ た対象へのアンケート結果ではあるが，今後，メ ディアを通じた広報に加え，スーパーマーケット やコンビニエンスストアなど身近な場所で購入で きる場所を増やし，それについて消費者に伝える という, 購入に結びつけるための具体的取組みと 情報提供の両方を進めることが今後販売量を増加 させるために重要だといえる。

\section{4. まとめ}

1974 年に日本でフェアトレードが始まってか ら約 40 年が経過した。その間日本国内では, 1994 年ごろからフェアトレードが新聞に掲載されるよ うになり，1995 年ごろから出版物が発行されるよ うになった。新聞への掲載は 2008〜2010年に最も 多く，その後減少していたが, WFTOによると日 本のフェアトレード認証製品推定市場規模は 2004 2013 年の 10 年間で約 26 倍に増加してい た。今後, エシカルやソーシャルな消費の一つと してフェアトレード製品を選択する人が増加し, それに伴いフェアトレード認定市場規模は今後も 拡大していくと予測される。ここで注目したいの は, フェアトレードについての報道の増加などの 社会的関心の高まりに伴い,フェアではないト レードの存在について認識する人が増加し, 国際 フェアトレード認証ラベルの有無に関わらず，倫 理的な製品を選ぶ消費者が増加してきたという社 会の変化である。この変化こそが, フェアトレー ドの普及による真の成果といえるのではないだろ
うか。

\section{謝辞}

本稿の作成にあたって, 広島大学の中坪孝之教 授に貴重な助言を頂いた。また広島大学附属高等 学校のアンケートは, Natural style Harmony の 木村英隆氏, 広島大学附属高等学校の伊藤直哉 氏，藤原隆範氏，そして回答してくれた生徒の皆 さんのご協力で実施できた。ここに記して，心か ら感謝の意を表する。

\section{注瀵}

1) フェアトレード・ラベル・ジャパン (FLJ), http:// www.fairtrade-jp.org/, 2014 年 11 月 28 日閲覧.

2 ) NGO (Non-Government Organization)：世界的 な問題に対して，取り組む非政府組織.

3 ) International Fair Trade Associationの略. 1989年 に設立された団体で, オランダに事務局がある, http:// www.wfto.com/, 2014 年 11 月 10 日最終閲覧.

4) 2012 年末時点で 71 ケ国の 386 団体が加盟し，情 報を共有しながらともにフェアトレードの普及を 目指している（WFTO，2013）.

5 ) Fair Trade Federationの略. 北アメリカに本部を 置いている, http://www.fairtradefederation.org/, 2014 年 11 月 10 日最終閲覧.

6 ) 1998 年に FLO (Fairtrade Labelling Organizations International, 国際フェアトレードラベル機構, 1997 年設立), IFAT, NEWS! (Network of European World shops, ヨーロッパ・フェアトレード・ネッ トワーク, 1994 年設立), EFTA (Europe Fair Trade Association, ヨーロッパ・フェアトレード協会, 1987 年設立）がそれぞれの頭文字をとって，形成した非 公式なネットワーク，会合を行い，WTOの閣僚会 議に代表を派遣している.

7 ）当時各国に展開されていた日本を含む 14 のフェ アトレードラベル推進組織によって, アンブレラ組 織として 1997 年設立された, http://www.fairtradejp.org/, 2015 年 9 月 28 日最終閲覧.

8 ）特定非営利活動法人シャプラニール＝市民による 海外協力の会は, 1972 年に設立された, 特定の宗教, 政治, 企業, 団体には属さない, 日本の国際協力 NGO で, 南北問題に象徵される現代社会のさまざまな問 題, とりわけ南アジアの貧しい人々の生活上の問題 解決に向けた活動を, 現地と日本国内で行い,「すべ ての人々がもつ豊かな可能性が開花する社会の実 現」を目指して, 活動している. 1974 年よりバング ラデシュの手工芸品の生産と販売活動をはじめ, 
2003 年より「クラフトリンク」と言う名前でフェア トレード活動を開始し, インターネットなどを通じて バングラデシュ・ネパールのフェアトレード製品を 販売している, http://www.shaplaneer.org/about/ outline.html, 2015 年 1 月 7 日閲覧.

9 ) 1993 年に設立されたフェアトレードラベル推進組 織で, FLOの構成メンバー，2002 年に完成した世 界統一の国際フェアトレード認証ラベルの導入と $\mathrm{NPO}$ 法人化にともない 2004 年に「フェアトレード. ラベル・ジャパン $(\mathrm{FLJ}) 」$ と名称を変更した, http:// www.fairtrade-jp.org/, 2014 年 11 月 28 日閲覧.

10） Fair Trade Student Network の略. 2004 年に設 立されたフェアトレードを知りたい, 広めたいと考 える学生を中心としたネットワークで, 関東支部, 関西支部, 北海道エリア, 北陸エリア, 九州エリア があり, それぞれで活動している他, FTSN ジャパ ンとしても活動している, http://www.ftsnjapan. $\mathrm{com} /, 2014$ 年 11 月 29 日閲覧.

11）まちぐるみ・地域ぐるみでフェアトレードを推進 する「フェアトレードタウン運動」の国内での普及 を目指すフェアトレードタウン・ジャパン（FTTJ） という市民団体から生まれた。2011年の熊本市の フェアトレードタウン認定や 2014 年 3 月の熊本で 開催したフェアトレードタウン国際会議の開催な どを行った. 2014 年 10 月 15 日に, 日本フェアト レード・フォーラム $(\mathrm{FTFJ})$ へと変更した, http:// www.fairtrade-forum-japan.com/, 2015 年 5 月 12 日 閲覧.

12）FLJ「国際フェアトレード認証＼cjkstart認証・登録組織一 覧」, http://www.fairtrade-jp.org/license/traders_ 2014.09.17.pdf, 2014 年 11 月 30 日閲覧.

13）全国の 15 歳以上 79 歳以下の男女個人を対象に新 聞, テレビ, ラジオ, 雑誌, インターネットの 5 メ ディアへの接触状況や利用, 評価を尋ねた結果, 各 メディアへの接触率は頻度を問わない場合, 1 位テ レビ (98.0\%)，2 位新聞（朝刊） (83.2\%)，3 位雑誌 (68.2\%)，4 位インターネット $(66.8 \%) ， 5$ 位ラジオ (52.4\%) の順で, 毎日接触する人の割合では 1 位テ レビ (88.1\%), 2 位新聞 (朝刊) $(56.4 \%), 3$ 位イン ターネット (48.6\%), 4 位ラジオ (18.5\%), 5 位雑 誌 $(2.8 \%)$ という結果であった.

14）回答者 412 名のフェアトレード認知情報源は, テ レビ地上波 (15.5\%), 新聞 (14.1\%), 雑誌 $(12.6 \%)$, 店頭 (10.9\%)，インターネットHP (9.0\%) の順に 高かった。

15）国立国会図書館法（昭和 23 年法律第 5 号）によ り，国内で発行された全ての出版物を国立国会図書 館に納入することが義務付けられている.

16）全国の公共図書館, 公文書館, 美術館や学術研究
機関等が提供する資料, デジタルコンテンッを統合 的に検索できるサービス. 自然文検索, あいまい検 索，類義語・同義語検索等を用いて検索を行ってい る, http://iss.ndl.go.jp/, 2014 年 7 月 23 日閲覧.

17）「記事・論文」には, 学術誌に掲載されている論 文と学会誌や団体誌や一般雑誌に揭載されている 記事の両方が含まれるが，ここでは一つのものとし て取り扱う。

18）ここでいう「新聞」というのは「フェアトレード」 をテーマに発行された新聞のことで, 新聞に掲載さ れた記事数とは異なる。

19）朝日新聞社の 1879 年（明治 12 年）の創刊号から 現在までのオンライン記事データベースである. 「朝日新聞 1985 , 週刊朝日・AERA 全文記事デー タベース」では, 沖縄を除く 46 都道府県の全地域 面を収録しており，地域のニュースもくまなく検索 できる, http://database.asahi.com/library2/, 2014 年 9 月 10 日閲覧.

20）日本経済新聞社の日本経済新聞（朝刊・夕刊），日 経産業新聞, 日経 MJ (流通新聞), 日経地方経済面 の記事や企業・人事情報他の検索・閲覧ができる日 本経済新聞データベース, http://t21.nikkei.co.jp/ g3/CMNOF12.do, 2014 年 9 月 10 日閲覧.

21）WFTO が，毎年 5 月の第 2 土曜日を「世界フェ アトレード・デー (WFTD: World Fair Trade Day)」と提唱し, 世界中でフェアトレードについて のイベントが開催されている, http://www.wfto. com/index.php?option $=$ com_frontpage\&Itemid $=1$, 2014 年 9 月 17 日閲覧.

22） 1972 年 6 月 5 日からストックホルムで開催された 「国連人間環境会議」を記念して毎年 6 月 5 日が「環 境の日」と定められた，国連では，日本の提案を受 けて 6 月 5 日を「世界環境デー (World Environment Day)」と定めており, 日本では「環境基本法」(平成 5 年）が「環境の日」を定めている, 環境省の HP http://www.env.go.jp/guide/envdm/より拔粋. 2014 年 9 月 17 日閲覧.

23）国連は, 1950 年（昭和 25 年）12月 4 日の第 5 回 総会において, 世界人権宣言が採択された日である 12 月 10 日を「人権デー」と定めた。 日本では，法 務省と全国人権擁護委員連合会が, 同宣言が採択さ れたことを記念して, 1949 年から毎年 12 月 10 日を 最終日とする 1 週間を,「人権週間」と定めている, 法 務省 http://www.moj.go.jp/JINKEN/jinken03. $\mathrm{html}, 2014$ 年 9 月 17 日閲覧.

24） 1987 年に設立された国際的な NGO で, 生物多様 性の保護と人々の持続可能な生活の確保を使命と して活動している。農業, 林業, その他の業種で適 切な認証・検証基準を満たした製品に, 認証マーク 
を使用できるよう認証を行っている，http://www. rainforest-alliance.org/ja 2015 年 5 月 27 日閲覧.

25）おいしいコーヒーの真実, http://www.uplink.co.jp/ oishiicoffee/, 2014 年 9 月 8 日閲覧.

26）同調査では，「消費者市民社会への展望」をテー マに，政府による調査として，環境配慮行動と合わ せて初めてフェアトレードを取り上げた（渡辺 2013).

27）2009 年の消費者庁発足に伴い，「国民生活白書」 を作成した内閣府国民生活局が廃止され，以降同白 書は発行されていない. 2013 年度より「消費生活白 書」が発行されているが,「消費者行動」について の調査で商品やサービスの選択時に「経営方針や理 念, 社会貢献活動」について意識するかを問う記述 があるだけで, フェアトレードについての記述は確 認できなかった。

28）独立行政法人大学入試センター, http://www. dnc.ac.jp/, 2015 年 10 月 5 日閲覧.

29）文部科学省「学校基本調査－平成 27 年度（速報） 概要」, http://www.mext.go.jp/b_menu/toukei/ chousa01/kihon/kekka/k_detail/1360721.htm, 2015 年 10 月 5 日閲覧.

30) People Tree, http://www.peopletree.co.jp/ event/wftd/list_2015.html, 2015 年 8 月 7 日閲覧.

31） 1942 年にイギリスで設立され，世界 93 力国で活 動する国際協力団体. 世界 17 の国・地域に拠点を 置き, 貧困を克服しようとする人々を支援し, 貧困 を生み出す状況を変えるために活動している，オッ クスファム・インターナショナルはその国際的連合 体, http://oxfam.jp/, 2015 年 8 月 10 日閲覧.

32) FLO, http://www.fairtrade-jp.org/, 2015 年 8 月 10 日閲覧.

33）渡辺（2013）は，フェアトレードという言葉を見 聞きしたことがある，ないし知っている割合をフェ アトレード (という言葉) の「知名度」, フェアト レードを貧困ないし環境の問題に関わる言葉であ ると知っている人の割合を「認知率」と定義し, 2008 年はチョコレボ実行委員会マーケティングチーム が実施した「フェアトレード認知・市場ポテンシャ ル調査」(2009 年 1 月), 2012 年は一般社団法人フェ アトレードタウン・ジャパンが実施した「フェアト レードと倫理的消費に関する全国調査」(2013 年 2 月 26 日）を元に認知率を推定している.

34）経済産業省の定義による，http://www.meti.go.jp/ policy/local_economy/sbcb/, 2014 年 12 月 2 日閲覧.

35） 1970 年代に Agriculture と Forestry から作られ た造語。植栽木間の空き地に野菜などを栽培し, 農 業収益と林業収益を可能にする農業と林業との複 合経営. 農林複合経営とも言われる．参考：http:// www.eic.or.jp/ecoterm/?act=view\&serial=39, 2015 年 5 月 27 日閲覧.

36）特定非営利法人開発教育協会，公益財団法人かな がわ国際交流財団 (2006)，新・貿易ゲーム（改訂 版）を利用.

\section{参考文献}

阿久沢麻理子（1998）「フィールド・ノート行動 する人権 (1)「する・される」関係を越える一 フェア・トレードの試み」『ヒューマンライツ』 127 号, 14-21 頁.

FLO, NEWS!, IFAT, EFTA, 北澤肯, フェア トレードリソースセンター（2008）『これでわか るフェアトレードハンドブックー世界を幸せに するしくみ』合同出版.

堀田正彦（2003）「環境保全型農業の現状 フェア トレードと有機農業」『自然と農業』8 号, 56-58 頁.

Janet Dine, Kirsteen Shield（2007a）「企業の社会 的責任一企業はフェア・トレードを行う責任が あるか (上)」『国際商事法務』Vol.35, No.3, 316-322 頁.

Janet Dine, Kirsteen Shield (2007b)「企業の社会 的責任一企業はフェア・トレードを行う責任が あるか (下)」『国際商事法務』Vol.35，No.4， 489-497 頁.

金田晃一（2007）「フェアトレードと CSR の関係 一「環境」,「人権」から「自立」配慮の視点へ」 『ステークホルダーズ :「良き企業市民」となる ための情報誌』2007 年度 1 号, 20-22 頁.

久賀みず保, 山尾政博（2001）「生協によるフェア トレードと海外産地一よどがわ市民生協と夕イ 農民グループとのバナナ取引」『協同組合研究』 21 巻 2 号, 60-76 頁.

マイケル・バラット・ブラウン，青山薰，市橋秀 夫（1998）『フェア・トレード: 公正なる貿易を 求めて』, 新評論.

皆川万葉 (2002)「オリーブオイルのフェアトレー ドでパレスチナとつながる」『未来』No.429, 10-13 頁.

望月洋孝 (2009)「日本におけるフェアトレードの 展開とその推進主体に関する研究」,東京農業大 学 (博士論文).

長坂寿久（2008a）『日本のフェアトレード一世界 
を変える希望の貿易』明石書店.

長坂寿久（2008b）「『世界のフェアトレード市場 2007 年』(FINE/DOWS) 報告書概説」『国際貿 易と投資』No74, 134-150 頁.

長坂寿久 (2009)『世界と日本のフェアトレード市

場』明石書店.

内閣府（2008）『平成 20 年版国民生活白書』時事 画報社.

中村良光（2007）「ISO とフェアトレード」『生活

協同組合研究』No.383, 64-67 頁.

サフィア・ミニー（1995）「フェア・トレードー

“貿易”を通して参加する「持続可能な社会」づ

くリ」『産業と環境』vol.276, 11 月号, 123-127 頁.

妹尾 裕彦 (2009)「コーヒー危機の原因とコーヒー

収入の安定・向上策をめぐる神話と現実一国際

コーヒー協定（ICA）とフェア・トレードを中

心に」『千葉大学教育学部研究紀要』第 57 巻,

203-228 頁.

辻村英之（2003）「途上国産一次産品のアンフェ

ア・トレードの分析枠組：タンザニア産コーヒー

のフードシステムとフェア・トレード」『農林業

問題研究』第 39 巻第 3 号, 241-251 頁.

渡辺龍也（2013）「フェアトレードと倫理的消費

（ I ）～全国調査が明らかにするその動向〜」『東

京経済大学現代法学会』第 25 巻, 135-174 頁.

渡未絢（2009）「フェアトレード：90 年代以降か

ら見る現在の動向 (1)」『横浜国際社会科学研究』

第 14 巻第 3 号, 151-176 頁.

渡末絢（2010）「フェアトレード：90 年代以降か
ら見る現在の動向 (2完)」『横浜国際社会科学研 究』第 14 巻第 5 号, 133-155 頁.

渡未絢（2013）「低炭素都市・フェアトレードタウ ンの統合的まちづくりに向けたフェアトレード の役割」『横浜国際社会科学研究』第 22 巻第 2 号, 133-155 頁.

安田利枝（1998）「フェア・トレード: 問題点と可 能性」『嘉悦女子短期大学研究論集』第 41 巻第 2 号, 85-118 頁.

佐藤寛 (2009)「フェアトレード研究のためのブッ クレビュー」『アジ研ワールド・トレンド』No. No.163， 39-42 頁.

チョコレボ実行委員会マーケットリサーチチーム 「フェアトレード・マーケットリサーチくサマ リー>」2007 年 7 月 22 日, http://choco-revo.net/ pdf/ftreport_chocorevo.pdf, 2014 年 8 月 12 日閲 覧.

日本新聞協会 広告委員会 $(2014)\lceil 2013$ 年 全国丈 デイア接触・評価調查」, http://www.pressnet. or.jp/adarc/data/research/pdf/2013media/ report_web_2013.pdf, 2014 年 9 月 9 日閲覧.

WFTO (2009) "World Fair Trade Organization Annual Report 2008", http://www.wfto.com/ index.php?option $=$ com_content\&task=view\&id $=26 \&$ Itemid $=109,2014$ 年 10 月 30 日閲覧.

WFTO (2013) “World Fair Trade Organization Annual Report 2012”, http://www.wfto.com/ index.php?option $=$ com_content\&task $=$ view \&i $\mathrm{d}=26 \&$ Itemid $=109,2014$ 年 10 月 31 日閲覧.

(2015 年 8 月 21 日受付, 2015 年 11 月 19 日受理) 